\title{
SOBRE AS DISJUNÇÕES ENTRE DIREITO E JUSTIÇA: \\ AS PRÁTICAS DE RACIONALIDADE DA INJUSTIÇA \\ OPERADAS PELO SUPREMO TRIBUNAL FEDERAL NO \\ CASO DA DEMARCAÇÃO DA TERRA INDÍGENA \\ RAPOSA SERRA DO SOL
}

\section{ABOUT THE DISTINCTIONS BETWEEN LAW AND JUSTICE: PRACTICES OPERATED BY THE SUPREME COURT IN THE CASE OF THE DEMARCATION OF THE RAPOSA SERRA DO SOL INDIGENOUS LAND}

Anabelle Santos Lages*

Introdução

Localizada em uma região de fronteiras internacionais, Roraima está distante dos grandes centros urbanos do Brasil. Por essa razão, desde o século XVII, holandeses e espanhóis estabeleceram relações com seus habitantes quando percorreram essa área, antes mesmo da chegada oficial de ingleses e portugueses (FARAGE, 1991; REPETTO, 2008). Não data de hoje a disputa pelo território daquela região, conhecida também como Rio Branco - nome do rio que corta o estado de Roraima, inclusive sua capital,
Boa Vista. No entanto, se agora a posse dessa porção de terra brasileira foi objeto de litígio entre índios e não índios, no século XVIII a delimitação dos contornos do território nacional na forma como o conhecemos só foi possivel por causa dos povos indígenas (FARAGE, 1991). Os portugueses chegaram ao rio Branco na segunda metade do século XVIII com a missão de impedir o que acreditavam ser o avanço do tráfico de escravos indígenas por parte dos holandeses situados na costa da Guiana. Ainda que isso não tenha ocorrido de forma explícita, a tensão entre portugueses e holandeses

* Possui graduação em Direito pela Pontifícia Universidade Católica de Minas Gerais, mestrado e doutorado em Sociologia pela Universidade Federal de Minas Gerais. Atualmente é bolsista PNPD do programa de Pós-Graduação em Sociologia na Universidade Federal de Alagoas (Maceió/AL/Brasil). anabellelages@yahoo.com.br. 
impulsionou a consolidação de um discurso de colonização para a área.

Protagonistas dessa história, os povos do rio Branco estavam presentes nas estratégias de colonização dos dois países: a adesão política dos índios representava a garantia de conquista do território. Desse modo, não há como aceitar a prevalência de qualquer tipo de discurso que sustente uma total passividade indígena em relação à sua história; ao contrário, a delimitação da colônia esteve diretamente vinculada às estratégias e arranjos de forças estabelecidos pelas e entre as etnias que viviam na região à época. Nesse sentido, não é mero acaso que um parecer de 1695, elaborado pelo Conselho Ultramarinho, observasse que "os gentios erão as Muralhas dos Certoens" [sic] (FARAGE, 1991). "O domínio entre pessoas e nações passava pelo exercício do controle do solo" (MEDEIROS, 2009, p. 221).

Tais informações nos fornecem indícios para desconfiar do argumento, apresentado pelos partidários da demarcação em ilhas no momento da disputa judicial sobre a validade do processo administrativo da demarcação da Terra Indígena Raposa Serra do Sol (TIRSS), de que a demarcação, da forma como foi homologada, teria reunido etnias rivais, pois isso fixa os indígenas numa posição de passividade na medida em que desconsidera os arranjos e relações de poder e dominação estabelecidos entre os Macuxi, Pantamona, Ingaricó, Wapichana e Taurepang ao longo de todo o processo de colonização. Como constatado em diversos relatos de viajantes e missionários, os povos indígenas vivenciaram intensos processos de fusão e reagrupamentos sociais (FARAGE, 1991; SANTILLI, 1992). Mesmo num momento anterior a uma prática colonizadora mais ostensiva, há notícias de que a ocupação colonial já produzia, um século antes, alterações na composição étnica e demográfica daquela região. Incontroverso é o fato de que a ocupação portuguesa produziu processos de depopulação, extinção e fortalecimento de alguns povos indígenas (FARAGE, 1991; SANTILLI, 1992).

Uma das principais plataformas de "agentes sociais e governamentais comprometidos com formas dominantes de gestão local" (SANT'ANA JÚNIOR, 2012, p.10) contra a demarcação das terras indígenas diz respeito aos obstáculos que ela causaria ao “desenvolvimento". Roraima tem 46\% de sua área demarcada, a maior parte em forma de ilhas. Aliás, essa maneira de demarcar era condizente com uma política que pretendia inserir os índios na sociedade nacional. Algumas dessas terras sequer apresentam a diversidade de recursos naturais necessários à reprodução do modo de vida indígena. Nesse sentido, foram as demarcações ocorridas em áreas consideradas vastas do estado que incrementaram a indignação e tornaram conhecidos os conflitos na região. Delimitadas conforme as normas estabelecidas na Constituição da República de 1988, as Terras Indígenas Yanomami e as Terras Indígenas Raposa Serra do Sol representam a vitória dos indígenas na luta para vivenciarem seus direitos (ISA, 2012).

Embora a extensão destas linhas não nos permita adentrar nessa discussão, a longa história da demarcação mostra que a definição dos perímetros territoriais da Terra Indígena Raposa Serra do Sol, ainda que estes tenham sido formalizados pelo processo administrativo e declarados válidos pelo STF, demonstra o papel fundamental que teve, na conquista desse direito, a capacidade de organização das etnias envolvidas, das comunidades organizadas e das associações que se estabeleceram entre elas. Além disso, tais perímetros apresen- 
taram "um caráter inovador no sentido de que representam definições diferentes em relação à ação pública, [...] em resposta a desafios gerados pela globalização e pelos requisitos do desenvolvimento sustentável (SANT'ANA JÚNIOR, 2012, p. 10), que são a todo o tempo trazidos para o debate apenas em sua forma discursiva.

\section{Da incomunicabilidade entre direito e justiça}

A leitura do voto em agosto foi fantástica, foi magnífica, foi incrivel, ficava todo mundo com medo do "mais". Não, em algum momento Ele vai falar do "mais" e aí o sonho acabou (Advogada do Instituto Socioambiental, entrevista concedida em julho de 2012).

A ameaça da quase personificação do “mais”, trazido no excerto acima, dá a medida da expectativa na qual estavam envoltas as pessoas que, no dia 27 de agosto de 2008, acompanhavam a primeira sessão do julgamento pelo Supremo Tribunal Federal (STF) da Petição 3388/RR, destinada a decidir sobre a regularidade do procedimento administrativo que demarcou de maneira contínua a Terra Indígena Raposa Serra do Sol. 0 “mas” (em forma de "mais") expressava a apreensão de que os termos daquele voto não fossem definitivos, nem a decisão integral. E, de fato, a conjunção adversativa apareceu nas mais de dez condicionantes estabelecidas pelo ministro Menezes de Direito, espécie de marco regulatório para o reconhecimento da validade da Portaria 534/2005, do Ministério da Justiça, homologada pelo Presidente da República em 15 de abril de 2005, que estabeleceu os limites da TIRSS.

No dia 19 de março de 2009, na segunda sessão do julgamento, o STF declarou constitucional o modelo contínuo da de- marcação, derrubando a liminar que garantia a presença dos não índios nas terras das cinco etnias que vivem no local: Macuxi, Taurepang, Patamona, Wapichana e Ingarikó. Todavia, ainda que proferida a partir da aplicação de regras do direito, colocou-se em suspensão a ideia de que o STF teria decidido com Justiça. Mesmo que não restem dúvidas sobre a indignação que a decisão provocou nos defensores de um modelo fracionado, e mesmo que manifestações proclamando que "a justiça havia sido feita" fossem expressões comuns entre os partidários da integralidade daquele território, ou exatamente porque ambos viam no direito o instrumento que lhes poderia fornecer Justiça, consideramos importante dissociá-la do direito.

A despeito da desvinculação entre direito e justiça não constituir exatamente uma novidade, os processos e mecanismos através dos quais o Supremo Tribunal Federal legitima decisões que são justas apenas numa perspectiva retórica ainda não são bem conhecidos. Muito disso tem a ver com o fato de seus membros estarem envoltos numa atmosfera de sacralidade ao mesmo tempo em que são apresentados como experts da ciência jurídica. As práticas do que chamamos de racionalidade da injustiça só são possíveis porque estão assentadas na técnica do direito e de todos os atributos simbólicos que contribuem para a legitimidade daqueles que são escolhidos para integrar a principal Corte do país. Com isso em vista, como se verá, o estudo da decisão proferida pelo STF no caso da demarcação da Terra Indígena Raposa Serra do Sol ajuda-nos a visualizar os caminhos percorridos por uma razão que operou a separação entre Justiça e Direito.

Um episódio ocorrido em 2004 durante a luta pela demarcação da TIRSS contribui 
para visualizarmos a crítica feita à banalidade do mal por Arendt (1983), bem como a separação que a autora faz entre a Justiça e o Direito. 0 senador Mozarildo Cavalcanti (um dos futuros autores da Petição 3388/ $\mathrm{RR}$ ), os deputados Luciano Castro (PL/RR) e Suely Campos (PP/RR) e o indígena Caetano Raposo (conhecido defensor da demarcação em ilhas) impetraram mandado de segurança pedindo liminarmente a anulação dos efeitos da Portaria 820/98 (posteriormente reeditada como Portaria 534/2005, foi publicada em decorrência do laudo antropológico das terras feito pelo Grupo de Trabalho interdisciplinar instaurado em 1992). A liminar foi concedida, suspendendo os efeitos da Portaria, que esperava apenas a homologação do Presidente da República para ser efetivada.

Para que pudesse ser concedido, o pedido de liminar deveria vir acompanhado da ocorrência de fatos novos, posto que a Portaria 820/98 já tinha sido objeto de questionamento jurídico outras vezes. Surpreendentemente, o juiz entendeu que o anúncio do Ministro da Justiça, Márcio Tomaz Bastos, de que o Presidente da República, em breve, assinaria o decreto de homologação, bem como os conflitos que se seguiram entre índios e fazendeiros, constituiam fatos novos. Também considerou fato novo a designação feita pelo Ministro ele de uma “comissão de experts” para elaborar perícia interdisciplinar na Ação Popular (n. 199914-7), também sob sua competência, que tramitava na $1^{\text {a }}$ Vara Federal de Roraima, por considerar que "a matéria fático-jurídica é de alta indagação e demanda maiores reflexões e amadurecimento" ${ }^{1}$. Em julho de 2004, esse mesmo juiz determinou que os indígenas saíssem da TIRSS para que os fazendeiros pudessem ser reintegrados às suas terras (YAMADA, 2010a).

As liminares concedidas por esse juiz ajudam a demonstrar a incomunicabilidade entre direito e Justiça (ARENDT, 1993). Ainda que se desconsidere que, desde o início do século XX, há uma violência endêmica naquela área - com relatos de incêndio nas aldeias, invasões e sequestros (SANTILLI, 2010) -, que a homologação pelo Presidente da República constitui ato subsequente à publicação de uma portaria demarcatória e, ainda, que a constituição de estudo interdisciplinar numa ação que já estava em curso há cinco anos não possui o status de fato novo, a concessão das liminares pelo juiz deu-se conforme os postulados do direito, principalmente em razão do princípio do livre convencimento. Princípio esse que permite ao juiz formar a sua convicção a partir da livre apreciação das provas e que, a depender da forma de sua admissão, pode levar ao esvaziamento dos valores ao equipará-los (ARENDT, 1983) e, assim, autorizar a realização de cálculos jurídicos como o abaixo transcrito:

Na perícia está muito claro, você é bacharel em direito, vai concordar que aí nessa questão, havia aí uma relação de ponderação, uma ponderação de direitos. Conflito de direitos fundamentais, com outros direitos e outros interesses também constitucionalmente relevantes. E esse conflito é resolvido pela técnica da ponderação, ou da reciprocacedência [princípio da cedência recíproca]. E o STF decidiu pelo tudo ou nada. Pelo voto do Ayres Britto, era tudo ou nada. Tudo Raposa, nada os outros interesses. Outros inte-

1. Posteriormente, essa Ação Popular foi extinta pela declaração de competência do STF para julgar o caso da TIRSS, o que aconteceu com a Petição 3388/RR. 
resses são: questão da segurança, questão da autonomia do Estado, questão da existência de dois municípios lá dentro, questão dos direitos de propriedade, da existência de títulos de domínio já existentes, legitimados (Juiz Federal de Roraima. Entrevista concedida em julho de 2012, grifos nossos).

Tais cálculos podem ser vistos tanto como os desentendimentos (RANCIÈRE, 1996) existentes entre os operadores jurídicos acerca do que seria um direito passível de proteção, quanto como a equivalência niilista dos valores denunciada por Arendt (1983). Em relação à elaboração proposta por Rancière (1996, p.11), a dissonância não reside em sua identificação formal (“o desentendimento não é de modo algum desconhecimento"), perfeitamente elencada na Constituição e nos demais dispositivos legais, mas na sua manifestação substantiva. No fragmento de entrevista, o juiz federal comenta o voto do ministro relator, que reconheceu os direitos originários dos índios ao território. Para ele, juntamente com o direito de propriedade, restariam prejudicados a autonomia do estado de Roraima e o direito à segurança. 0 desentendimento reside no fato de que, embora ambos estivessem falando de direitos, o direito ao território e os direitos à propriedade e à segurança não são compreendidos da mesma maneira, gerando um aniquilamento do direito ao território, em relação ao qual fazem jus os indígenas Isso fica mais claro quando o juiz equipara esses mesmos direitos a interesses, "era tudo Raposa, nada os outros interesses", querendo dizer que os direitos de propriedade e da livre iniciativa foram deixados de lado frente aos direitos dos indigenas.

A imprecisão no uso das palavras direito e interesse não deve ser tomada como um mal-entendido; ao contrário, a crítica por parte do magistrado de que a técnica da ponderação não foi utilizada mostra que o desentendimento não é “o conflito entre aquele que diz branco e aquele que diz preto mas não entende a mesma coisa” (RANCIÉRE, 1996, p.11). Atravessa toda essa problemática o princípio da igualdade, sem o qual não subsistiria o atual sistema democrático, igualmente contestado pelo autor em Hatred of Democracy (RANCIÈRE, 2006). Ao mesmo tempo em que está institucionalizada no ordenamento jurídico, perpassando discursivamente todas as esferas de atuação governamental, a igualdade não integra o funcionamento dessas esferas, tampouco está presente num ordenamento constitucional ou nos costumes de uma sociedade (RANCIĖRE, 2004). Ela está num movimento permanente de inconformidade com a maneira como o poder nos constitui como sujeitos.

A democracia não é uma forma institucional, ela é, antes de tudo, a própria política, isso é, o fato de que ajam como governantes aqueles que não têm diploma de governo, nem competência para fazê-lo. De uma certa maneira, a democracia é o poder dos incompetentes, isto é, ela é a ruptura das lógicas que fundam um modo de governo sobre uma suposta competência: a democracia é, pois, a interrupção das lógicas da desigualdade (RANCIĖRE, 2003, p. 201).

Juridicamente, essa igualdade institucionalizada vem sempre acompanhada dos preceitos da neutralidade e da universalidade de direitos, mas são exatamente esses predicativos que obscurecem os conflitos e as relações de poder entre as partes. Para tanto, a afırmação, “de que não há nada para além da história” (BOURDIEU apud 
CHARTIER, 2002, p. 148) nos auxilia na problematização das categorias da universalidade, da neutralidade e da autonomia absoluta do direito. Incorporadas ao habitus do magistrado, tais categorias favorecem a manifestação de discursos ideológicos e transcendentais de justiça e de moral universal. Nessa direção, a reflexão sobre as categorias direito e justiça implica em sua retirada do plano das ideias para alocá-las nos embates, nas estratégias, no caminhar da história. Os membros do STF, por exemplo, permanecem revestidos por uma aura de sacralidade, de intocabilidade: "quem chega a uma cadeira na mais alta Corte do país, tornando-se agente vitalício do Estado, chega ungido, não tem de agradecer coisa alguma", declarou certa vez o ministro Marco Aurélio Mello (2001, p. 02).

De fato, raciocínios dessa natureza, bem como as transmissões ao vivo dos julgamentos pela TV Justiça e a frequência praticamente diária nos noticiários e jornais, não deixam dúvidas: eles são especiais. De acordo com Lahire (2002), assim como acontece com o nome próprio, a toga sobre seus ombros funciona como um direcionamento afetivo em relação ao qual há uma identificação simbólica dos seus portadores. No entanto, diferentemente do nome, expressão da identidade e individualidade do ser, a capa preta, além de "horizontalizar", entre os ministros, sua "missão" de guardar a Constituição do país, "iguala-os". No Brasil, os ministros do Supremo usam uma toga comprida, e mesmo que você participe de algum julgamento como advogado ou membro do Ministério Público, deverá usar uma capa mais curta, a beca (YAMADA, 2010a).

A pesquisa destinada a conhecer o estabelecimento do uso da toga pelos magistrados identificou nessa prática aquilo que Hobsbawm e Ranger (2002) chamaram tradição inventada. Ainda que não retornemos à Roma Antiga, não restam dúvidas de que, no Brasil, a indumentária tem sido formal e repetidamente institucionalizada ao longo dos anos. Observa-se que, a cada nova situação política vivenciada no país, ocorre uma imediata reação com vistas a reafirmar o seu uso, “estabelecendo seu próprio passado através da repetição quase que obrigatória” (HOBSBAWM \& RANGER, 2002, p.11) da norma, seja ela em forma de lei, decreto ou regimento interno. 0 uso da toga foi continuamente lembrado, não obstante o judiciário brasileiro ter experienciado certas mudanças em seus quadros (SADEK, 2006) .Em específico, a própria história do Supremo Tribunal Federal mostra a dinamicidade (ainda que talvez apenas discursiva) da instituição, do Poder Moderador destinado (por inspiração norte-americana) a garantir explicitamente a estabilidade social dos "donos do poder" (FAORO, 1975) aos ministros que proclamam o seu ofício de salvaguarda da Constituição, de uma forma que os aproxima de uma espécie de clérigos cívicos.

Hobsbawm e Ranger (2002) utilizam justamente a atividade judicante para diferenciar a tradição do costume: “'costume' é o que fazem os juízes; 'tradição' (no caso, tradição inventada) é a peruca, a toga e outros acessórios e rituais formais que cercam a substância, que é a ação do magistrado" (p. 11). Embora não seja obrigatório o uso da toga, a afırmação do ministro Mário Guimarães deixa clara a sua importância: “pela sua tradição e seu prestígio, é mais do que um distintivo, é um símbolo. Alerta, no juiz, a lembrança de seu sacerdócio. E incute no povo, pela solenidade, respeito maior aos atos judiciários" (GUIMARÃES, 1958, p. 195). 
Mas por que a percepção do magistrado, declarada há mais de 50 anos, ainda nos parece pertinente? Ou, dizendo de outra forma, haveria uma concordância tácita entre críticos e adeptos acerca do caráter solene e sacerdotal trazido pela toga? A respeito dos elementos não racionais, Hobsbawm e Ranger (2002) afirmam que, juntamente com o aparecimento da política de massas, "governantes e observadores da classe média redescobriram sua importância na manutenção da estrutura e da ordem social” (p. 277), e lembram o comentário feito por Graham Wallas em Human Nature in Politics, de que "quem se dispuser a basear seu pensamento político numa reavaliação do funcionamento da natureza humana, deve começar por tentar superar sua própria tendência de exagerar a intelectualidade do homem" (HOBSBAWN; RANGER, 2002, p. 277).

Da mesma forma que a toga se tornou um símbolo ritualizado, já que, tradicionalmente, os ministros entram e saem do plenário com ela sobre os ombros, outros rituais performáticos também circundam os julgamentos realizados pelo plenário do STF, ou seja, quando os onze ministros estão reunidos. Antes de entrarem no recinto e após colocarem a capa preta, os ministros posicionam-se em fila ordenada pela antiguidade na casa. Os assentos, dispostos em forma de "u", também recebem os magistrados conforme a regra referente ao tempo de nomeação; nas duas pontas mais distantes do presidente, sentam-se os ministros que ingressaram no STF mais recentemente. Ainda, a despeito do regimento interno não estabelecer, até hoje - com a exceção de 1943, quando Getúlio Vargas outorgou-se a indicação de presidente por decreto -, quem ocupa a presidência do STF, esta tem sido representada rotineiramente pelo ministro mais antigo. No entanto, nunca se prescin- diu da cerimônia na qual todos os ministros depositam seu voto em uma urna em forma de cálice, carregada por um funcionário. Embora a contagem dos votos caiba ao membro mais novo, na prática ela seria desnecessária, tendo em vista que o ministro mais antigo sempre vence as eleições.

Nenhum desses rituais possui, em si, algum elemento substantivo que influencie ou determine de forma objetiva a função de julgar à qual os ministros estão adstritos, o que nos poderia levar à conclusão de que seriam apenas um fim em si mesmo. No entanto, a energia e os poderes emanados pelos símbolos faz-nos recordar a teoria durkheimiana sobre a religião, preocupada em conhecer não apenas as crenças que a mobilizam, mas o papel desempenhado pelos rituais sociais realizados por seus membros; tomar a religião como um fenômeno não racional nos ajuda a compreender os desdobramentos morais e as ideias simbólicas mobilizadas pelos rituais sociais (DURKHEIM, 1996). Collins (1982) sustenta que as aplicações dessa teoria vão além da esfera religiosa, contribuindo para a explicação das ideologias políticas, bem como sobre os setores seculares privados da vida moderna, e ligando as condutas do cotidiano às práticas e crenças religiosas primitivas.

A (con)sagração inicia-se com a colocação da toga na sala, que antecede o plenário. Tal qual o crucifıxo para os cristãos, ela tanto identifıca o ministro como "focaliza a ideia do grupo sobre si mesmo" (COLLINS, 182, p. 9). Em seguida, reúnem-se os ministros, discursivamente mobilizados e unidos à salvaguarda da Constituição da República, conforme estabelece o próprio ordenamento.

0 poder do grupo é a sua energia e a sua força moral mas, para as pessoas é difícil entender diretamente. Por participarem do grupo, 
elas não podem vê-lo como ele é. Elas devem representar a sua realidade sob uma forma concreta. Elas a reificam. Passam a acreditar que ele é uma coisa real, quase física. Assim, as pessoas concebem como um objeto sagrado o espírito que as mobiliza e une. É o animal totêmico em cujo nome elas se reúnem, ou o Deus para o qual rezam. Na versão política moderna, ele é a nação, o partido ou a ideia política (por exemplo democracia, ou socialismo ou revolução) pelo qual elas sentem que estão lutando (COLLINS, 1982, p. 08).

À primeira vista, as análises dos símbolos da justiça e da performance ritualística praticada por seus atores dentro da arena judicial pode parecer em desalinho com a ideia de racionalidade, tão cara aos magistrados. No entanto, é justamente o resultado da amálgama desses elementos que possibilita às instituições judiciais e seus atores, sobretudo aqueles incumbidos de decidir, usufruírem de um forte esquema de reconhecimento e de legitimidade na sociedade. No que diz respeito à racionalidade, na próxima sessão deste artigo, serão analisados alguns procedimentos adotados por parte do Ministro da Justiça - em determinada fase da luta pela demarcação da Terra Indígena Raposa Serra do Sol - e pelos ministros do Supremo Tribunal Federal na ocasião do julgamento. Em comum, adianta-se que ambas as intervenções foram apresentadas como técnicas de aprimoramento do processo demarcatório.

Antes, dentro da possibilidade destas linhas, pretende-se mostrar que as grandes certezas axiomáticas que acompanham, ao menos discursivamente, o pensamento dos juristas, deitam suas raízes na passagem do século XVIII para o século XIX. Especialmente no que diz respeito ao direito, a modernidade, apresentada como "desacralizadora y demoledora de mitos, se muestra por el contrario como gran constructora de los mismos” (GROSSI, 2003, p. 40). Os ideários de racionalidade jurídica pregados pelo Iluminismo Jurídico da Europa continental, em relação ao qual o direito brasileiro deve toda a sua origem, trouxeram o princípio da igualdade jurídica, bem como os preceitos da neutralidade e da universalidade, cujos desdobramentos podem ser encontrados nos institutos do devido processo legal, ampla defesa e contraditório, por exemplo. ${ }^{2}$ Por detrás desses postulados, a filosofia jurídica que os amparava era "religiosa", no sentido de que atribuía à mente do indivíduo, à razão, significado definitivo e santo. Dentro desse contexto, a racionalidade jurídica, juntamente com o individualismo e o nacionalismo, compunham o que Berman (1983,

2. Os princípios da neutralidade e da igualdade juridical estão imediatamente vinculados aos do contraditório e da ampla defesa, que, juntos, constituem o chamado devido processo legal., 0 art. $5^{\circ}, \mathrm{LV}$ da CRFB/88 diz: “Art. $5^{\circ}$ Todos são iguais perante a lei, sem distinção de qualquer natureza, garantindo-se aos brasileiros e aos estrangeiros residentes no País a inviolabilidade do direito à vida, à liberdade, à igualdade, à segurança e à propriedade, nos termos seguintes:(...) LV - aos litigantes, em processo judicial ou administrativo, e aos acusados em geral são assegurados o contraditório e ampla defesa, com os meios e recursos a ela inerentes;(...)”. Segundo Di Pietro (2007, p.367): “0 princípio do contraditório, que é inerente ao direito de defesa, é decorrente da bilateralidade do processo: quando uma das partes alega alguma coisa, há de ser ouvida também a outra, dando-se-lhe oportunidade de resposta. Ele supõe o conhecimento dos atos processuais pelo acusado e o seu direito de resposta ou de reação. Exige: 1- notificação dos atos processuais à parte interessada; 2- possibilidade de exame das provas constantes do processo; 3- direito de assistir à inquirição de testemunhas; 4- direito de apresentar defesa escrita”. 
p.45) chamou de "santíssima trindade da democracia”. Além de expressarem um esforço para tornar mais previsíveis as consequências jurídicas, "foram considerados úteis e justos, integrantes da ordem natural do universo" (BERMAN, 1983, p.45), como se a razão e a consciência dos homens de bem só pudesse emanar direitos justos e legítimos. Os ideais de racionalidade trazidos pelo Direito Natural e pelo Direito Positivo são explicitados pela máxima de que toda lei, toda decisão judicial deve estar em conformidade com as exigências constitucionais do devido processo. São a doxa do nosso direito contemporâneo, numa acepção bourdieusiana (1989). 0 argumento de "racionalidade" utilizado pelos juízes e acompanhado pelos demais atores do campo do direito mostram-se eficazes na objetificação das subjetividades presentes nas decisões jurídicas, cujo viés político muitas vezes não se deseja assumir. Aliás, como observa Berman (1983, p. 24) a respeito da cláusula do devido processo, “o Estado e os poderes que o governam, ou a classe dominante, beneficiam-se dela e 'desejam-na"”.

No entanto, paralelamente, a supressão da metafísica religiosa pelo processo de secularização produziu uma lacuna negativa para a nova razão jurídica, conferindo-lhe certa fragilidade. A necessidade de produção de uma metarrealidade satisfaz-se com a força emanada pelos sagrados símbolos e pelos rituais do universo jurídico, mas também por uma ideia de racionalidade do direito calcada em fictícios preceitos de igualdade, neutralidade e universalidade jurídica. Assim, a racionalidade do direito, coberta pela toga e enobrecida por ritos e anéis, transformou-se no principal braço da democracia liberal, no dizer de Berman (1983, p. 45), “a primeira grande religião secular da história do ocidente”.
No que diz respeito aos juízes, sujeitos aos quais se confere a competência legítima para manejar tudo isso, estes passam a ser vistos como os novos ocupantes de uma autoridade clerical e ou paternal, deixada no vazio por seus antigos titulares (GARAPON, 1996). Nessa perspectiva, considerando que o discurso jurídico não prescinde do exercício de um ritual, conferindo aos seus sujeitos propriedades e papéis especiais, ele "defıne a qualifıcação que devem possuir os indivíduos que falam”, gestos e comportamentos e demais sinais que acompanham o discurso (FOUCAULT, 1970, p. 11). Temse, portanto, um importante elemento para a configuração do poder e da dominação por parte de determinados atores na arena do direito.

Tudo isso parece fazer parte daquilo que Evgeni Pachukanis (1988) chamou de fetichismo jurídico. Para o jurista russo, autor de A Teoria Geral do Direito e Marxismo,

0 Estado jurídico é uma miragem que muito convém à burguesia, uma vez que substitui a ideologia religiosa em decomposição e esconde aos olhos das massas a realidade do domínio da burguesia. A ideologia do Estado jurídico convém mais ainda do que a ideologia religiosa porque ela não reflete completamente a realidade objetiva ainda que se apóie nela (PACHUKANIS, 1988, p. 100).

Pensando na indicação dos ministros do Supremo Tribunal Federal, e considerando que o saber técnico e científico também pertence ao universo do sagrado, exigências como "notável saber jurídico" e o compromisso com um julgamento exclusivamente técnico e constitucional fazem parte da construção de uma realidade ficcional na qual tanto ministros quanto os "sujeitos de direito" parecem acreditar na possibilidade de um jul- 
gamento não político e/ou ideológico. No que diz respeito ao STF, responsável pela proteção da Constituição, a dificuldade de perceber a impossibilidade disso torna-se ainda maior e suscita denúncias e/ou críticas de que a decisão ou determinado ministro não estaria consonante a um preceito maior. Explicando melhor, acredita-se que, realmente, seja possível julgar exclusivamente conforme a lei, deixando de lado quaisquer pressupostos da esfera subjetiva. Quando um ministro acusa o outro de não julgar conforme a Constituição ou de estar sendo parcial, reforça-se a crença de que seria possivel para alguém fazê-lo de forma não subjetiva.

Alguns elementos (ou discursos) propiciam a formação dessa miragem. Consideramos, em específico, que o princípio da igualdade jurídica, o respeito às normas constitucionais e a proteção ao Estado Democrático de Direito são retóricas que acompanham os participantes do jogo social ("jogos que se fazem esquecer como jogos”) e que participam também desse processo (BOURDIEU, 2001, p. 139). Aliás, como se verá na próxima seção, a necessidade de se preservar o chamado "devido processo legal" foi um dos suportes para a tessitura de uma decisão judicial assentada em uma lógica que é apresentada como sendo racionalmente imprescindível, mas cujos efeitos são injustamente distribuídos.

\section{Sobre a racionalização da injustiça: \\ o julgamento}

De volta à descrição do cenário do julgamento da decisão da demarcação da Terra Indígena Raposa Serra do Sol. Após a campainha que anuncia o início da sessão, os onze ministros entram enfileirados no plenário do Supremo Tribunal Federal. Em contraste com as vestimentas que os dife- renciam dos demais, o edifício projetado por Oscar Niemeyer nivela juízes e plateia. Os lugares de seus assentos no balcão em forma de "U" não são aleatórios. No centro, o presidente; no lado direito, o Procurador-Geral da República e, no lado esquerdo, o secretário da seção. Na cadeira mais próxima à direita do presidente, senta-se o decano da Casa. Os demais lugares são ocupados de acordo com a antiguidade da nomeação: nas duas pontas mais distantes do presidente sentam-se aqueles cuja nomeação é mais recente. Decoram o salão um painel de mármore bege com a imagem de Jesus crucificado, de Athos Bulcão, e a bandeira do Brasil (YAMADA, 2010a).

No dia 27 de agosto de 2008 , as 376 cadeiras do plenário estavam ocupadas; ainda de madrugada a fila para a sessão já estava sendo formada. A monotonia monocromática dos "brancos em longos trajes negros" (YAMADA, 2010a, p.144) era quebrada pelo colorido dos trajes de gala usados pelas diversas lideranças indígenas do Brasil. A TV e a rádio Justiça transmitiam o julgamento ao vivo. Transcorridos os procedimentos introdutórios, os advogados dos autores da Petição 3388/R e os advogados dos réus apresentaram suas alegações. Pela primeira vez, um indígena falou no STF (YAMADA, 2010a): Joênia Batista de Carvalho, a qual, vestindo a beca, mas com o rosto pintado, fez sua defesa na língua wapichana.

A terra indígena não é só casa para morar, mas o local onde se caça, onde se pesca, onde se caminha e onde os povos indígenas vivem e preservam sua cultura. A terra não é um espaço de agora, mas um espaço para sempre. Queremos viver conforme nossos usos e costumes, conforme nossas tradições, num ambiente de harmonia e respeito com todos (CARVALHO, 2008). 
Após os pronunciamentos dos advogados das partes envolvidas, o ministro relator do caso, Ayres Britto, iniciou a leitura de seu voto, conforme previa o regimento interno do STF. 0 ministro utilizou com frequência referências literárias e musicais, como quando votou, amparado no pedido de Goethe por "mais luz na humanidade", pela constitucionalidade das pesquisas com células-tronco embrionárias. Essa maneira pouco convencional de dizer o direito fez com que Britto se tornasse conhecido como um ministro liberal, que votou também a favor da derrubada da lei de imprensa e a favor da união entre pessoas do mesmo sexo. Ao decidir sobre o aborto de fetos anencéfalos, disse que "o grau de civilidade de uma sociedade se mede pelo grau de liberdade da mulher". Também votou a favor da revisão da lei da anistia, entendendo que ela não significou um perdão para os torturadores. Seu estilo peculiar de decidir adjetivou o cargo por ele ocupado; passou a ser identificado como o "ministro poeta". Essa referência vem sempre carregada de ironia ou de admiração, dependendo tanto do interlocutor quanto do que está em disputa, como no trecho abaixo, retirado de um blog criado em 2006 por simpatizantes do presidente Luiz Inácio Lula da Silva:

Data Vênia, já vai tarde, Ayres Britto. Que vá fazer "poesia" bem longe do STF.

E, pelo-amor-de-Deus presidenta Dilma, nunca mais escolha alguém que se diga um “juiz poeta” para ser ministro do STF. Juízes não devem viajar na imaginação dos poetas para julgar. Devem ater-se ao concretismo da razão. A poesia visa transmitir emoções, mais do que comunicar informações. Exatamente o contrário do que se es- pera das sentenças judiciais. Juízes não devem ocupar seus neurônios com a rima, no momento em que devem dissecar com detalhismo a verdade mais profunda dos autos. Juízes não devem produzir sentenças sobre a vida alheia com estrofes que só ele julga espirituosas. Sentenças judiciais pedem clareza e objetividade cartesiana, pra não pairar dúvidas. Jamais parábolas barrocas ou rococós. Poeta que se preze é utópico, libertário, revolucionário, vira a razão e a realidade do avesso, anarquiza, diverte, emociona, encanta, é fantasioso, surreal. Tudo o que não deve ser feito em um processo jurídico. Já juíz que se preze é fiel aos rigores da razão, da lógica, da realidade objetiva e, é raro mas existem, ao método científico. Ayres Britto, como juiz foi um mau poeta, e como pretenso poeta foi um mau juiz. Pelo menos no trato da Ação Penal 470 3 (BLOG “AMIGOS DO PRESIDENTE LULA”, 2012).

Relator da resposta à Petição 3388/RR, Ayres Britto decidiu pela constitucionalidade do modelo contínuo da demarcação da Terra Indígena Raposa Serra do Sol e seu voto foi acompanhado por nove dos dez integrantes do STF. Posteriormente, em entrevista, disse estar "feliz da vida" com a sua decisão e, ao falar sobre os caminhos que percorreu para a formação de suas razões de decidir, afırmou ter ocorrido uma transformação em sua maneira de enxergar a causa indígena. No início, diz ele, sua cabeça era "de branco", pensava "como é que se reserva tanta terra para índio?”. Mas, a partir de um estudo criterioso da Constituição da República, o ministro foi, aos poucos, mudando de opinião, aprendendo: "Eu comecei Buffalo Bill e terminei Touro Sentado. Foi assim que o meu voto começou

3. Ação que envolveu os acusados de compra de votos, conhecido como Mensalão. 
e terminou" (BRITTO, 2009). Na decisão da TIRSS, citou Einstein: "É mais fácil desintegrar um átomo que um preconceito".

A despeito do ministro Gilmar Mendes ter iniciado seu voto com as lembranças do tempo em que era aluno externo do Seminário Jesus Maria José, em Diamantino (Mato Grosso), relatando a convivência com os índios em sua infância, os debates e posicionamentos anteriores ao longo de sua carreira faziam crer que o voto do ministro seria pela restrição dos direitos indígenas. De acordo com Yamada (2010b), o julgamento dos Mandados de Segurança 21.896/ $\mathrm{PB}$, sobre a demarcação da Terra Indígena Jacaré de São Domingos, e 25.463/DF, sobre a demarcação da Terra Indígena Ñanderu Marangatu, bem como a Ação Civil Ordinária 312/BA, sobre a Terra Indígena Caramuru Paraguassu, e os Mandados de Segurança 21.649 e 24.045 exemplificam os precedentes anti-indígenas do ministro.

Quando ocupava o cargo de Procurador da República, Gilmar Mendes, juntamente com o então ministro da defesa Nelson Jobim, participou ativamente da elaboração do Decreto n. 1774, de janeiro de 1996, que substituiu o Decreto regulatório n. 22, de 04 de fevereiro de 1991. 0 novo decreto atrasou a demarcação da Terra Indígena Raposa Serra do Sol em aproximadamente sete anos, já que a identificação feita em 1993 e que originou a demarcação da área pela Portaria 820 de 1998 (revogada por meio da Portaria 534/2005) perdeu a validade com a regulação superveniente. À época, o argumento utilizado por Gilmar Mendes para a mudança na norma, presente novamente na Petição 3388/RR, foi a necessidade de se regularizar o procedimento do contraditório e da ampla defesa, garantindo "àqueles que seriam ou poderiam ser afetados por um ato drástico, o ato de demarcação, que com a configuração administrativa da declaração da área indígena, afırma a inexistência da propriedade" (BRASIL, 2008, p. 765).

0 novo decreto viria a alcançar as terras já demarcadas bem como aquelas cuja demarcação ainda se encontravam em curso, como é o caso da Raposa Serra do Sol. Os críticos sustentaram que se tratava de manobra procrastinatória impermeabilizada por dois dos principais institutos jurídicos do processo administrativo e judicial, o do contraditório e o da ampla defesa (DALLARI, 2002). Ademais, os processos de demarcação de terras indígenas, que já deveriam ter sido concluídos desde 1993, conforme estabelecido pela própria Constituição de 1988, tiveram em seu caminho argumentações favoráveis à defesa do direito de propriedade.

0 Decreto 1775/96 estabelece que, do início do processo de demarcação até 90 dias após a publicação do resumo do relatório circunstanciado produzido pelo grupo técnico, estados, municípios e outros interessados podem apresentar as suas razões para obstar o procedimento. Após receber parecer da Fundação Nacional do Índio (Funai) sobre as razões e provas apresentadas, cabe ao Ministro da Justiça desaprovar a identificação, requerer diligências complementares ou declarar, mediante portaria, os limites da terra indígena. A incongruência desses dispositivos reside no fato de que, muitas vezes, o processo administrativo de demarcação possuirá maior celeridade do que os desdobramentos judiciais advindos desse decreto. Ademais, não se pode nunca perder de vista que o artigo 20, XI, da CR/88 estabelece que "são bens da União as terras tradicionalmente ocupadas pelos índios" e que o parágrafo 6 do artigo 231 enfatiza que "são nulos e extintos, não produzindo efeitos jurídicos, os atos que tenham por objeto a ocupação, o domínio e a posse das 
terras" indígenas. Carecem de validade jurídica, portanto, não apenas as terras oriundas de invasões, mas também doações, vendas e compras de qualquer espécie. Por essa razão, o jurista Dalmo Dallari, em artigo publicado no jornal Folha de São Paulo, em 08 de maio de 2002, argumentou:

Já no governo Fernando Henrique, o mesmo Dr. Gilmar Mendes, que pertence ao Ministério Público da União, aparece assessorando o ministro da Justiça Nelson Jobim, na tentativa de anular a demarcação de áreas indígenas. Alegando inconstitucionalidade, duas vezes negada pelo STF, 'inventaram' uma tese jurídica, que serviu de base para um decreto do presidente Fernando Henrique revogando o decreto em que se baseavam as demarcações (DALLARI, 2002).

A introdução do contraditório e da ampla defesa no procedimento administrativo de demarcação de terras indígenas pode, à primeira vista, ser entendida pelos operadores do direito como algo natural e obrigatório. A instituição da prevalência desses institutos frente à garantia do direito à posse originária das terras indígenas redefine as regras do jogo da demarcação após tal decisão do STF. Como anotou Bourdieu (2001), a principal diferença entre um campo e um jogo é que o primeiro abarca a própria disputa pelas regras do jogo. Portanto, consideramos que a decisão do STF resultou em uma disputa pelo "campo". A instituição de novas exigências para a demarcação de terras indígenas, articulada por um representante do Ministério Público e um integrante do poder executivo, não objetivava a suspensão indeterminada do procedimento de demarcação iniciado, ou mesmo, grosso modo, a revogação desse direito constitucional. Contudo, consideran- do o papel regulador que o sistema jurídico desempenha no interior dos agrupamentos sociais, a alteração do ordenamento parece fazer parte de mecanismos elaborados pelo próprio campo jurídico-político quando o mesmo se viu ameaçado.

O sucesso da articulação de Jobim e Mendes resultou de suas respectivas posições na estrutura, bem como de seu capital agregado (BOURDIEU, 1989). A confusão entre as esferas de competências dos agentes públicos possibilita que o Procurador da República (à época, deslocado para a função de assessor Técnico do Ministério da Justiça na gestão do ministro Nelson Jobim, em 1995 e 1996) e o Ministro da Justiça, sob o argumento de contribuir para o aperfeiçoamento dos instrumentos legais, viabilizem a concretização de ambições de certas classes, mas apresentadas como racionais e universais. Anos mais tarde, o criador da norma, agora ministro do Supremo Tribunal Federal, teria a oportunidade de aplicar sua própria lei.

Santilli (2001) observa que, embora as evocações sobre a segurança nacional, tão comuns nas décadas de 1970 e 1980, não tenham desaparecido por completo, o discurso do aprimoramento legal e institucional veio a substituí-las, contribuindo para silenciar as reivindicações por Justiça. Observa-se que certas doxas do direito ocidental moderno, como o devido processo legal, são colocadas a serviço de práticas que se consubstanciam antidemocráticas na medida em que procrastinam a garantia de um Direito reconhecido como originário. Esse aperfeiçoamento pode ser visto tanto na decisão da Raposa como nas propostas de transferência, ao Congresso Nacional, da competência para aprovar as demarcações de terras indígenas, como prevê o Projeto de Emenda Constitucional n. 215, atualmente 
sob a análise de uma comissão da Câmara dos Deputados (BRASIL, 2013). A esse movimento de formulação de soluções jurídicas para questões pertencentes à esfera da consolidação de direitos que se encontram na iminência de serem estabelecidos dou o nome de racionalização da injustiça.

No caso da demarcação da Terra Indígena Raposa Serra do Sol, pode-se identificar esse mecanismo sendo utilizado pelo menos mais algumas vezes. Após a leitura do voto pelo ministro relator, o ministro Carlos Alberto Menezes de Direito pediu vista ao processo. 0 pedido de vista interrompe o julgamento e constitui uma faculdade, quando um ministro deseja analisar melhor a ação. Na prática, principalmente em casos polêmicos, essa prerrogativa serve para que o ministro que pediu vista possa votar de forma divergente do relator na retomada do julgamento; assim como retirar o processo do foco de atenção da sociedade ainda que de forma momentânea, sob o argumento da falta de clareza sobre algum ponto a ser julgado. No limite, também funciona como a possibilidade de convencimento dos demais ministros nos bastidores (YAMADA, 2010a, p. 04).

De fato, foi isso o que aconteceu. Após o pedido de vistas em agosto de 2008, o julgamento só foi retomado em dezembro do mesmo ano com a leitura do voto parcialmente divergente do ministro Menezes de Direito. De acordo com a percepção de Yamada (2010. 04), o ministro sabia que um voto contrário à demarcação contínua "não seria bem recebido pela maioria do plenário, o que o colocaria numa posição desconfortável”. Menezes de Direito estabeleceu 19 condicionantes à demarcação. Embora algumas condicionantes sejam apenas reprodução da Constituição da República em seu capitulo sobre os índios, muitas são contrárias ao estabelecido na Convenção 169 da Organização Internacional do Trabalho, inovam a questão, alteram os contornos do processo e "criam direito", ou seja, legislam, numa clara expressão de invasão de competências.

As condicionantes foram consideradas por alguns estudiosos do direito como sendo (BRITTO, 2009) uma inovação jurídica e, por outros, inconstitucionais (YAMADA, 2010; SILVA, 2009), uma vez que ultrapassaram os termos do pedido inicial dos autores populares, que foi o da nulidade do processo administrativo que determinou a demarcação contínua da área da Terra Indígena Raposa Serra do Sol. Algumas delas criavam direito novo: como a proibição de acréscimo na extensão e a revisão de terras já demarcadas, fato que poderia provocar, inclusive, uma discussão sobre se houve ou não certo ativismo judicial. Caracterizado tanto por um novo clericalismo dos juízes, quando há uma forte corporação, ou, quando não for esse o caso, pelo destaque individual de alguns deles, muitas vezes com o auxílio midiático, esse tipo de ativismo tem em comum o desejo de influenciar nos rumos da sociedade; os direcionamentos dependerão das visões de mundo do magistrado (GARAPON, 1996).

Embora o resultado final tenha sido favorável à TIRSS, o acolhimento das condicionantes pela maioria dos ministros sinalizou o quanto eles não estavam totalmente confortáveis em proferir aquela decisão. Mesmo com oito dos onze votos favoráveis à demarcação contínua, o ministro Marco Aurélio manteve seu pedido de vista, adiando por mais quatro meses o término do julgamento. Após esse período, no dia 18 de abril de 2009, procedeu à leitura de seu voto, que durou seis horas. Criticado pelo adiamento, deu a seguinte declaração: 
Em primeiro lugar, só estou submetido à própria ciência e consciência. Em segundo, não vou, antes de formalizar um pedido de vista, endereçar ao presidente Lula um pedido de permissão para fazê-lo. Cumpro meu dever com a toga nos ombros. Há 12 anos tenho tempo para me aposentar. E poderia sair, tenho convites para atuar em bancas de advocacia, para construir um patrimônio até maior do que o que acumulei até hoje. Não faço porque me realizo como homem servindo aos meus semelhantes nessa missão sublime que é a de julgar. Pedi vista porque o caso é seríssimo e exige uma reflexão. E fiquei muito decepcionado com a não observação do que sempre foi a liturgia do STF: de aguardar a devolução do processo pelo colega que pediu vista. Agora, o fato de ter-se alcançado oito votos não resulta no prejuízo do meu pedido de vista. Trabalho no caso com o mesmo entusiasmo que empreenderia se fosse o primeiro a votar a matéria (MELLO, 2008, grifos nossos).

0 ministro julgou totalmente procedente o pedido inicial, declarando nulo o processo administrativo que demarcou de maneira contínua a Terra Indígena Raposa Serra do Sol. Em seu entendimento, o processo continha inúmeros vícios, como a não audição de posseiros e titulares de domínio consideradas as terras envolvidas, levantamento antropológico e topográfico que não condizia com a realidade dos fatos e ausência de audição do Conselho de Defesa Nacional em relação às áreas de fronteira.

Ao analisar o julgamento de Eichmann, Arendt (1983) pondera sobre a recusa de alguns juízes em agir fora do ordenamento jurídico estabelecido, deixando, assim, de enfrentar os desafios do inusitado. Essa situação coloca em evidência a questão de como julgar na ausência de uma regra geral à qual um caso concreto se submeta e faça emergir o que a estudiosa considera ser um dos principais problemas morais de todos os tempos: a faculdade de julgar (ARENDT, 1983). 0 agravante do caso brasileiro devese ao fato de a prática judicante mostrar como o reconhecimento da alteridade pode ser mascarado por um discurso englobante, mesmo quando o ordenamento jurídico reconhece explicitamente a pluralidade cultural e a autonomia dos povos. A declaração da validade do decreto que homologou a demarcação da TIRSS, seguida das ressalvas que restringem a autonomia das comunidades indígenas sobre o uso de seu território, não comportam apenas a crítica feita por Arendt (1993) sobre a arte de julgar com coragem e criatividade; a racionalização da injustiça ocorreu por meio do reconhecimento da validade de laudos, de processos e da normatização constitucional sobre a matéria. A justiça, pertencente à ordem do incalculável, do "viver como ser distinto e singular entre iguais" (ARENDT, 2008, p. 191), não tem lugar na orquestração de abordagens destinadas a viabilizar a legalidade de decisões elaboradas para preencher as lacunas argumentativas. Lacunas essas que são geradas por um tipo de procedimento judicial cuja resposta foi dada aprioristicamente, sem deixar espaço para o reconhecimento da alteridade.

A figura mítica do magistrado, conquistada e reforçada por métodos racionais de interpretação da norma, dos postulados de imperatividade da lei e por todo o aparato performático sobre o qual comento no presente artigo, turva o caráter político e axiológico do direito e sacraliza o ideal de verdade jurídica. As funções exercidas pelas retóricas da autonomia e da neutralidade (BOURDIEU, 1989) ajudam a entender a produção automática dessa ideologia ra- 
cionalista do direito, dentro da qual parece inconcebível "a existência de cerca de dezenove mil índios em toda a extensão geográfica da área demarcada - uma área doze vezes maior que o Município de São Paulo, em que vivem cerca de onze milhões de habitantes" (BRASIL, 2008, p.567). A decisão do ministro Marco Aurélio inclui também o argumento do interesse público e transforma o direito ao território num "resgate de dívida histórica, simplesmente histórica" que se pretende fazer "a ferro e fogo", ou seja, não juridicamente.

Os operadores do direito deveriam, portanto, manter uma postura ascética capaz de garantir a neutralidade e a universalidade para as quais estariam vocacionados. No entanto, essa distância neutralizante apresenta-se tão artificial quanto o estabelecimento racional de uma igualdade entre os sujeitos de um conflito. Embora diga que "há sim a obrigação de o país demarcar as terras indígenas", o Ministro adverte ser a "proteção da propriedade privada" um direito humano (BRASIL, 2008, p.568). A retórica da inexistência de hierarquia entre os direitos é revelada quando, entre a obrigação de demarcar as terras indígenas e a proteção de propriedade privada - cujos títulos, vale lembrar, devem ser invalidados quando assentados em áreas tradicionalmente ocupadas por índios -, escolhe-se por amparar e reconhecer como legítima a propriedade privada. Nesse caso, aliás, enquanto a demarcação de território indígena é apresentada como uma obrigação, ou seja, algo do qual não poderíamos nos furtar (o que poderia ser interpretado como algo penoso, sacrificante), a propriedade é um direito humano.

\subsection{Súmula 650}

Tanto a decisão da Terra Indígena Raposa Serra do Sol, como mais recentemente a da Ação Civil Ordinária 312 - por meio da qual a Funai pedia a nulidade dos títulos de propriedade dos fazendeiros ocupantes das terras dos Pataxós-hã-hã-hãe no sul da Bahia - estão fundamentadas pelo precedente gerado pelo Recurso Extraordinário n. 219.983-3/SP, de relatoria do ministro Marco Aurélio. 0 precedente deu origem à súmula 650 do STF, que dispõe: "os incisos I e XI do art. 20 da Constituição Federal não alcançam terras de aldeamentos extintos, ainda que ocupadas por indígenas em passado remoto" (BRASIL, 2003).

A palavra súmula origina-se do latim summula, cujo significado é sumário, restrito, resumo. No direito brasileiro, uma súmula do STF sintetiza todos os casos parecidos, decididos da mesma maneira. Embora não possua um caráter absolutamente vinculativo, orienta futuras decisões ao registrar de forma objetiva interpretações pacíficas ou majoritárias daquele tribunal. No caso, a súmula refere-se aos incisos I e XI do artigo 20 da Constituição da República de 1988, que elenca quais são os bens da União, entre eles, os que atualmente lhe pertencem, os que lhe vierem a ser atribuídos e as terras tradicionalmente ocupadas pelos índios. É preciso notar também que, em 1967, o regime militar estabeleceu que as terras ocupadas pelos índios eram de propriedade da União. A decisão que deu origem à súmula refere-se ao Recurso Extraordinário n. 219.983-3/SP. Naquela ocasião, a União peticionou, dizendo que o imóvel estaria compreendido no perímetro do antigo aldeamento de índios de São Miguel e Guarulhos e, portanto, em terras que, segundo o sustentado, seriam de domínio da União, o que, por sua vez, poderia significar seu reconhecimento como terra indígena.

A decisão do Recurso Extraordinário relatado pelo ministro Marco Aurélio foi pela 
improcedência do pedido da União. Em seus termos, concluiu que

[...] a regra definidora do domínio dos incisos I e XI do artigo 20 da Constituição de 1988, considerada a regência sequencial da matéria sob o prisma constitucional, não alberga situações como a dos autos, em que, em tempos memoráveis, as terras foram ocupadas por indígenas. Conclusão diversa implicaria, por exemplo, asseverar que a totalidade do Rio de Janeiro consubstancia terras da União, o que seria um verdadeiro despropósito (BRASIL, 1998, p.12).

Tendo sido sumulada, a decisão pode orientar, como orientou, várias decisões. A interpretação determinante foi de que a norma constitucional de estabelecimento de terras indígenas, prevista nos artigos 231 e 232, prescreve um dado fático: que os índios estejam na posse da área, o que dá margem a interpretações que desconsiderem as expulsões e os esbulhos ocorridos antes e após a Constituição de 1988. As negativas dos ministros aos pedidos constantes nos casos de Guarulhos e dos Pataxós hã-hã-hãe estão sustentadas pelo argumento do não reconhecimento da atualidade da posse indígena. 0 ministro Marco Aurélio apresentou o mesmo argumento em seu voto no processo da Terra Indígena Raposa Serra do Sol, mas foi vencido.

O Decreto Federal n. 1775/1996 e a súmula 650 estão no mesmo "patamar de racionalidade”. 0 primeiro, como visto, diz respeito a uma tese jurídica elaborada com vista a revogar o decreto no qual, até então, as demarcações estavam baseadas. Sob o argumento de aprimoramento do devido processo legal, doxa do direito processual brasileiro, introduziu o princípio do contraditório no processo de reconhecimento de terras indígenas. Assim, repetindo, qualquer interessado pode apresentar embargos ao procedimento de demarcação desde o início do processo até 90 dias após a publicação do resumo do relatório circunstanciado produzido pelo grupo técnico. À época, o decreto foi bastante criticado por juristas e defensores da causa indígena, principalmente porque o $§ 6^{\circ}$ do artigo 231 já estabelecia como nulos e extintos, sem a produção de efeitos jurídicos, "os atos que tenham por objeto a ocupação, o domínio e a posse das terras" indígenas (BRASIL, 1996). Nem é preciso dizer sobre os enormes atrasos nas demarcações causados por essa possibilidade de apresentação de recursos.

\subsection{Condicionantes}

No Brasil, a relação entre o grupo indígena e o território por ele ocupado é mediada pelo Estado. A própria definição de terra indígena não é uma categoria antropológica ou sociológica mas aquela presente na Lei 6.001 , de 1973, o que afasta expectativas de uma demarcação que resulte de elaboração feita exclusivamente pela comunidade. Invariavelmente, o próprio processo administrativo recebe intervenções jurídicas e políticas, razão pela qual é recomendável uma etnografia dos aparelhos de poder que atuam de forma pontual na constituição das chamadas terras indigenas (OLIVEIRA FILHO, 1998). As estratégias mobilizadas na decisão judicial do caso da Terra Indígena Raposa Serra do Sol nos permitem visualizar que o processo de demarcação operado pelo Estado constitui-se como o resultado "de um feixe de propostas, legislações, interesses e estratégias de território que raramente expressam a representação fidedigna do que os grupos indígenas concebem como o próprio terri- 
tório" (OLIVEIRA FILHO, 2012, p. 371).

As dezenove condicionantes estabelecidas pelo STF à decisão da TIRSS são exemplos das operações e contornos empreendidos pelo Estado, cujos desdobramentos atingem o próprio núcleo da decisão. As condicionantes constituem uma inovação no ordenamento jurídico brasileiro, posto que ultrapassam os limites dos pedidos constantes na petição inicial dos autores populares, traçando parâmetros abstratos de conduta que não foram discutidos ao longo do processo. As ressalvas feitas pela Corte constituem uma atividade normativa que coloca em questão os princípios do Estado Democrático de Direito e a separação dos poderes, deixando de lado qualquer discussão com as partes interessadas (art. $5^{\circ}$, LIV, CR) ou mesmo com o restante da sociedade, uma vez que os comandos gerais e abstratos apresentados versam sobre direitos fundamentais constitucionalmente protegidos.

É preciso relembrar que os pedidos iniciais dos autores populares foram pela nulidade da Portaria 534/2005 e do Decreto Presidencial que homologou a demarcação da TIRSS. Nesse sentido, na apresentação de seus argumentos de defesa, as comunidades indígenas que desejavam a demarcação contínua levaram em conta aqueles pedidos. 0 acoplamento das condicionantes à decisão que entendeu correto o processo administrativo de demarcação gerou um conflito entre o que foi pedido pelos autores e a resposta do judiciário.

Portanto, não há como considerar válida a conexão entre o pedido de nulidade da Portaria 534/2005 e seu respectivo decreto homologatório, justificado na existência de erros no procedimento administrativo de demarcação da TIRSS, com condicionantes que versam sobre o usufruto de direitos indígenas, atuação das forças armadas e ve- dação da ampliação de áreas já demarcadas, por exemplo. A situação torna-se ainda mais insólita quando se tem em conta que o STF declarou aquele processo perfeitamente regular. Ademais, o próprio ministro Menezes Direito confirmou o dissenso entre o pedido e a decisão ao se referir às condicionantes como um "conjunto de prerrogativas e restrições atrelado à terra indígena”, demonstrando a não vinculação com o pedido dos autores. Ao criar um entendimento sobre o assunto, as condicionantes podem ser usadas como argumentos em outras ações, na medida em que passam a integrar a jurisprudência do Tribunal. Nesse ponto, havia uma pretensão de se estender a decisão da TIRSS a outros casos. Sobre essa vontade, o ministro Menezes Direito afirmou:

A partir da apreciação deste caso pude perceber que os argumentos deduzidos pelas partes são também extensíveis e aplicáveis a outros conflitos que envolvam terras indígenas. A decisão adotada neste caso certamente vai consolidar o entendimento da Suprema Corte sobre o procedimento demarcatório com repercussão também para o futuro. Daí a necessidade do dispositivo explicitar a natureza do usufruto constitucional e seu alcance (BRASIL, 2008, p. 420).

Para além de integrar o rol das jurisprudências daquela Corte, a formalização de parâmetros para as futuras demarcações, expressa nas dezenove condicionantes, pode ser vista na Portaria n. 303, da Advocacia-Geral da União (AGU), de 16 de julho de 2012, atualmente suspensa, mas que dispõe sobre o que se chamou de "salvaguardas institucionais" às terras indígenas. A justificativa do dispositivo seria a formalização da interpretação das unidades da AGU, aos moldes das ressalvas postas 
pelo Supremo Tribunal Federal no caso da Terra Indígena Raposa Serra do Sol. Recentemente, em 24 de outubro de 2013, foram julgados os Embargos de Declaração opostos para esclarecer a extensão da aplicabilidade das condicionantes. Embora o Supremo tenha voltado atrás e confirmado que a decisão atingiria apenas a TIRSS, não tendo, portanto, efeito vinculante (BRASIL, 2013), não se pode dizer que a questão tenha sido esgotada. A orientação da Portaria 303 ainda permanece em aberto, principalmente quando se considera que, embora o Advogado-Geral da União tenha recuado, afirmando que a implantação da Portaria estaria condicionada ao estudo da AGU, sua primeira manifestação após o julgamento dos embargos foi sobre a necessidade de observância da jurisprudência do STF (BRASIL, 2013).

Os argumentos em prol das condicionantes dizem respeito tanto a uma suposta necessidade de esclarecer o direito do usufruto indígena como também de operacionalizar a própria decisão a partir do que seria uma "proposição criativa", nos termos utilizados pelo ministro Carlos Ayres Britto (BRASIL, 2008, p. 634). Em específico, algumas condicionantes repetem o texto constitucional, outras restringem direitos e há, ainda, aquelas que inovam totalmente o disposto no ordenamento jurídico nacional. As condicionantes que restringem direitos e inovam versam sobre temas que podem ser categorizados como território, nação e Estado. Assim, alocamos as condicionantes $1,2,3,4,10,11,12,13$ e 17 no eixo território; as de número 5 e 6 referem-se à nação, e as ressalvas 7, 8 e 9 dizem respeito a questões atinentes ao Estado. As condicionantes 14 e 15 são repetições dos artigos 18 e $17, \S 1^{\circ}$, do Estatuto do Índio, respectivamente. A cláusula 18 é cópia quase in- tegral do artigo 231, § 4º da Constituição da República. Como se verá, o argumento do interesse público as acompanha, o que implica na inferiorização dos direitos indígenas face ao argumento da supremacia da coletividade:

1 - 0 usufruto das riquezas do solo, dos rios e dos lagos existentes nas terras indígenas pode ser relativizado sempre que houver como dispõe o artigo 231 (parágrafo $6^{\circ}$, da Constituição Federal) o relevante interesse público da União na forma de Lei Complementar;

2 - 0 usufruto dos índios não abrange o aproveitamento de recursos hídricos e potenciais energéticos, que dependerá sempre da autorização do Congresso Nacional;

3 - 0 usufruto dos índios não abrange a pesquisa e a lavra das riquezas minerais, que dependerá sempre de autorização do Congresso Nacional, assegurando aos índios participação nos resultados da lavra, na forma da lei; 4 - 0 usufruto dos índios não abrange a garimpagem nem a faiscação, devendo se for o caso, ser obtida a permissão da lavra garimpeira;

5 - 0 usufruto dos índios não se sobrepõe ao interesse da Política de Defesa Nacional. A instalação de bases, unidades e postos militares e demais intervenções militares, a expansão estratégica da malha viária, a exploração de alternativas energéticas de cunho estratégico e o resguardo das riquezas de cunho estratégico a critério dos órgãos competentes (o Ministério da Defesa, o Conselho de Defesa Nacional) serão implementados independentemente de consulta a comunidades indígenas envolvidas e à Funai;

6 - A atuação das Forças Armadas da Polícia Federal na área indígena, no âmbito de suas atribuições, fica garantida e se dará independentemente de consulta a comunidades indígenas envolvidas e à Funai; 
7 - 0 usufruto dos índios não impede a instalação pela União Federal de equipamentos públicos, redes de comunicação, estradas e vias de transporte, além de construções necessárias à prestação de serviços públicos pela União, especialmente os de saúde e de educação;

8 - 0 usufruto dos índios na área afetada por unidades de conservação fica sob a responsabilidade imediata do Instituto Chico Mendes de Conservação da Biodiversidade;

9 - 0 Instituto Chico Mendes de Conservação da Biodiversidade responderá pela administração da área de unidade de conservação, também afetada pela terra indígena, com a participação das comunidades indígenas da área, que deverão ser ouvidas, levando em conta os usos, as tradições e costumes dos indígenas, podendo, para tanto, contar com a consultoria da Funai;

10 - 0 trânsito de visitantes e pesquisadores não-índios deve ser admitido na área afetada à unidade de conservação nos horários e condições estipulados pelo Instituto Chico Mendes;

11 - Deve ser admitido o ingresso, o trânsito, a permanência de não-índios no restante da área da terra indígena, observadas as condições estabelecidas pela Funai;

12 - 0 ingresso, trânsito e a permanência de não-índios não pode ser objeto de cobrança de quaisquer tarifas ou quantias de qualquer natureza por parte das comunidades indígenas; 13 - A cobrança de tarifas ou quantias de qualquer natureza também não poderá incidir ou ser exigida em troca da utilização das estradas, equipamentos públicos, linhas de transmissão de energia ou de quaisquer outros equipamentos e instalações colocadas a serviço do público tenham sido excluídos expressamente da homologação ou não;

14 - As terras indígenas não poderão ser objeto de arrendamento ou de qualquer ato ou negócio jurídico, que restrinja o pleno exercício do usufruto e da posse direta pela comunidade indígena;

15 - É vedada, nas terras indígenas, qualquer pessoa estranha aos grupos tribais ou comunidades indígenas a prática da caça, pesca ou coleta de frutas, assim como de atividade agropecuária extrativa;

16 - As terras sob ocupação e posse dos grupos e comunidades indígenas, o usufruto exclusivo das riquezas naturais e das utilidades existentes nas terras ocupadas, observado o disposto no artigo 49, XVI, e 231, parágrafo $3^{\circ}$, da Constituição da República, bem como a renda indígena, gozam de plena imunidade tributária, não cabendo a cobrança de quaisquer impostos taxas ou contribuições sobre uns e outros;

17 - É vedada a ampliação da terra indígena já demarcada;

18 - 0s direitos dos índios relacionados as suas terras são imprescritíveis e estas são inalienáveis e indisponíveis;

19 - É assegurada a efetiva participação dos entes federativos em todas as etapas do processo de demarcação (BRASIL, 2008, p. 879).

As condicionantes que restringem o usufruto do território indígena evidenciam seu caráter jurídico-político, manifesto no não reconhecimento de formas distintas de uso e representação do espaço; a reivindicação pela demarcação vincula-se à necessidade de respeito às lógicas territoriais não hegemônicas no âmbito dos Estadosnação (O'DWYER, 2012, p. 331). Observase nos dispositivos anexados à decisão, um discurso que submete a autonomia das comunidades indígenas ao progresso que adviria da exploração dos recursos hídricos e minerais da região. Sant'Ana Júnior e Silva (2012) alertam sobre tentativas de se justificar discursivamente a apropriação 
territorial a partir de uma vocação do território à industrialização. De fato, ainda de acordo com os autores, o "ambiente é focalizado apenas a partir do seu potencial energético - recursos, localização, logística - de proporcionar ganhos para a indústria. As formas sociais e práticas territoriais são desconsideradas, invisibilizadas ou, até mesmo, desqualificadas" (2010, p. 161).

Quando o STF reconhece, com ressalvas, a dimensão retórico-argumentativa presente na primeira parte da decisão, sai de cena e permite a visualização de uma fronteira (MARTINS, 2009) que pretende definir os limites da cultura e da natureza a partir de interesses nacionais. Essa fronteira não pode ser reduzida apenas à questão geográfica, mas refere-se também às distintas “culturas e visões de mundo". Por meio de um "caráter litúrgico e sacrificial” (MARTINS, 2009, p.11) ou, nos termos da decisão, pela necessidade de se pagar "um preço por se viver em democracia” (BRASIL, 2008, p. 569), as condicionantes impostas marcam a recusa do outro ao "viabilizar a existência de quem o domina, subjuga e explora” (p. 11) por meio “de artifícios cênicos em que se concede o principal, enquanto se acolhem interesses divergentes, ainda que inconstitucionais" (YAMADA, 2010a, p. 152). 0 resultado é o deslocamento de uma discussão sobre direitos de cidadania para uma discussão sobre os potenciais econômicos dos territórios indígenas (ZHOURI, 2010).

As condicionantes que vão do número 1 ao 8 relativizam o usufruto das terras pelas comunidades indígenas na medida em que os argumentos de interesse público são adicionados à matemática desenvolvimentista. Assim, já na primeira ressalva, o uso dos lagos, solo e rios é relativizado, dependem das determinações da União. De acordo com a segunda condicionante, os indígenas não poderão vetar, por exemplo, a construção de uma usina hidrelétrica em suas terras, o que deixa o Congresso Nacional com plenos poderes para autorizar um empreendimento desse porte. As condicionantes 5 e 6 ampliam os poderes da política de defesa nacional dentro das terras indígenas. Em todos os casos, o direito dos povos indígenas a serem ouvidos não foi observado, consubstanciando ofensa ao disposto no art. $6^{\circ}$ da Convenção $n^{\circ} 169$ da Organização Internacional do Trabalho (OIT), que versa sobre a obrigação dos governos de consultarem os povos interessados, mediante procedimentos apropriados e através de suas instituições representativas, todas as vezes que forem tomadas medidas legislativas ou administrativas que os possa afetar de forma direta.

0 mesmo acontece quanto à instalação de equipamentos públicos federais em terras indígenas, autorizada pela condicionante de número 7. Colocados de forma genérica, não foram considerados os direitos originários sobre aquelas terras e nem ponderados os desdobramentos nocivos que tais empreendimentos podem causar às comunidades. Além dessas, as condicionantes 8 e 9 conferem prioridade ao meio ambiente em detrimento do respeito aos direitos fundamentais das comunidades indígenas. Novamente, sob o argumento da unidade e da harmonia constitucional, há preponderância de um direito sobre o outro, embora haja um discurso que nega a existência dessa hierarquização. Ao se manifestar contrariamente às condicionantes, o Ministério Público lembrou que, em casos de conflito, "o administrador da unidade de conservação, até pela sua posição institucional, [colocará] em primeiro plano a tutela ambiental, em detrimento do direito das 
comunidades indígenas" (BRASIL, 2009, p. 10). Da mesma forma, essa situação confere às comunidades uma posição meramente opinativa na administração da unidade de conservação, o que se mostra incompatível com o disposto no art. 15.1 da Convenção 169 da OIT, que versa sobre a proteção especial garantida aos povos interessados nos recursos naturais existentes na área, assegurando sua participação na utilização, administração e conservação desses recursos.

Sobre o trânsito de visitantes e a permanência de não-índios nas áreas da unidade de conservação, bem como na terra indígena, as condicionantes 10 e 11 não permitem que as comunidades decidam, ou mesmo opinem, a respeito. No caso de unidades de conservação, a decisão cabe ao Instituto Chico Mendes e, fora disso, à Funai. Essas condições maculam toda a filosofia presente na Constituição de 1988, posto que retornam ao modelo da tutela, tratando os indígenas como incapazes, sem direito a exercerem sua autonomia da vontade.

A condição 17 trata da vedação da ampliação de terra indígena já demarcada. Ao desconsiderar a ocorrência de eventuais erros ou vícios nas demarcações, a ressalva obstaculariza a solução sempre que dela resulte a ampliação de terras, o que vai de encontro ao princípio da imprescritibilidade do direito e desconsidera a dinamicidade da realidade. Como estabelece o artigo $231 \mathrm{da} \mathrm{CR} / 88$, as terras habitadas por povos indígenas devem ser asseguradas a eles de forma permanente, como também aquelas "imprescindíveis à preservação dos recursos ambientais necessários ao seu bem-estar e as necessárias à sua reprodução física e cultural, segundo os seus usos e costumes e tradições" (BRASIL, 1988). Outrossim, vícios no procedimento de demarcação e mudanças na dinâmica social devem autorizar as comunidades indígenas a requererem a ampliação de suas terras, o que se conclui com base nos próprios dispositivos constitucionais relativos à matéria. Além disso, a condicionante leva a crer que não existem outras formas de aquisição de terras indígenas que não a demarcação. No entanto, não existem óbices à aquisição de novas terras pelas formas tradicionais da legislação civil, como expresso no art. 32 e 39, III, da Lei 6.001/73.

\section{Considerações Finais}

Como visto ao longo deste artigo, no que diz respeito à produção de Justiça pelo Supremo Tribunal Federal brasileiro, esta está condicionada aos resultados da combinação entre a sacralidade da toga e os sagrados preceitos da ciência jurídica nos quais estão envoltos seus ministros. Em relação à decisão da demarcação contínua da Terra Indígena Raposa Serra do Sol, a fusão de um direito teoricamente emancipador e plural com uma prática jurídica imersa num universo de interesses e disputas resultou em uma aplicação ambígua da Constituição. A decisão, a despeito de reconhecer os direitos fundamentais territoriais dos indígenas, veda a ampliação de terras já demarcadas; não vislumbra riscos à soberania nacional ou ofensa à segurança territorial pelo fato da TIRSS estar em faixa de fronteira, mas amplia o poder das forças armadas para agir na região; reconhece o direito da livre manifestação da pluralidade cultural dos povos indígenas, mas submete o usufruto de suas terras a razões de interesse público, alocando os direitos indígenas numa posição de segunda categoria e numa situação de total insegurança jurídica.

Elaborados e acionados em distintos momentos, o decreto 1775/96, a súmula 650 e as condicionantes da Petição 3388/ 
RR são exemplos de práticas de racionalização da injustiça. Quando sujeitos autorizados se valem da legitimidade das leis e das regras de formalidade para contornar direitos e concepções de vida tidos como minoritários, produzem sentenças injustas, mas com efeito de verdade. Ao disporem da possibilidade de "explorar a polissemia ou a anfibologia das fórmulas jurídicas”, tirando "o máximo partido da elasticidade da lei e mesmo das suas contradições, das suas ambiguidades ou das suas lacunas" (BOURDIEU, 1989, p. 224), os juízes e legisladores, amparados por um corpo técnico altamente especializado e em princípios jurídicos inquestionáveis, produzem mecanismos que se destinam à garantia de estabilidade de sua classe.

\section{Referências}

ARENDT, H. Eichmann em Jerusalem: um relato sobre a banalidade do mal. São Paulo: Diagrama ct Texto, 1983.

BLOG “AMIGOS DO PRESIDENTE LULA". Data Vênia, já vai tarde, Ayres Britto. Que vá fazer "poesia" bem longe do STF, 14 nov. 2012. Disponivel em: http://osamigosdopresidentelula. blogspot. com.br/2012/11/data-venia-ja-vai-tarde -ayres-britto.html. Acesso em: 10 nov. 2013.

BERMAN, H. Direito e Revolução: A formação da tradição jurídica ocidental. São Leopoldo: Unisinos, 1983.

BOURDIEU, P. 0 poder simbólico. Rio de Janeiro: Bertrand Brasil, 1989.

. Meditações Pascalianas.Rio de Janeiro:

Bertrand Brasil, 2001.

BRASIL. Casa Civil. Decreto 1.326, de 10 de fevereiro de 1854. Marca o vestuário, que, no exercício de suas funcções e solemnidades publicas, devem usar os Juizes de Direito, e JuizesMunicipaes e de Orphãos, e Promotores Públicos. Disponível em: http://www.planalto.gov.br/ ccivil_03/decreto I Historicos/DIM/DIM1326.htm. Acesso em: $14 \mathrm{dez}$. 2013.

BRASIL. Planalto Central. Homologa a demarcação administrativa da Terra Indígena Raposa Serra do Sol, localizada nos Municípios de Normandia, Pacaraima e Uiramutã, no Estado de Roraima. Disponível em: http://www.planalto.gov.br/ccivil_03/_ Ato2004-2006/2005/Dnn/ Dnn10495.htm. Acesso em: 22 mar. 2011.

BRASIL. Supremo Tribunal Federal. Regimento Interno: [atualizado até dezembro de 2013] - consolidado e atualizado até maio de 2002 por Eugênia Vitória Ribas. Brasília: STF, 2013.

BRASIL. Supremo Tribunal Federal. Súmula n. 650 do STF, de 24 de setembro de 2003. Dispõe sobre Bens da União. Brasília, 2003. Disponível em: http://www.dji.com.br/normas_inferiores /regimento_interno_e_sumula_stf/stf_0650.htm. Acesso em: 15 jun. 2012.

BRASIL. Decreto Federal n. 1775/1996, de 08 de janeiro de 1996. Dispõe sobre o procedimento administrativo de demarcação das terras indígenas e dá outras providências. Brasília, 2008.

BRASIL. Supremo Tribunal Federal. Tribunal Pleno. Sessão de 10 de dezembro de 2008. Disponível em: <http://videos.tvjustica.jus.br/>. Acesso em: 10 dez. 2008.

BRASIL. Supremo Tribunal Federal. Petição n. 3388/RR. Relator Ministro Carlos Ayres Britto. Brasília: TSF, 2008. Disponivel em: http://www. stf.jus.br/portal/principal/principal.asp. Acesso em: 11 mar. 2010.

BRASIL. Justiça Federal. Ação Popular n. 199914-7. Arquivada na $1^{\text {a }}$ Vara da Justiça Federal da Seção Judiciária de Roraima.

BRITTO, C. A. Ayres Britto: não à cultura de branco. Correio Brasiliense, Brasília, 06 abr. 2009.

CARVALHO, J. B. Sustentação Oral proferida por ocasião da votação da Petição 3388, 27 ag. 2008. Disponivel em: http://www.youtube.com/watch?$\mathrm{v}=\mathrm{aEcROgWHjmk}$. Acesso em: 22 jan. 2012. 
COLLINS, R. The Sociology of God. In: COLLINS, R. Sociological Insight: an introduction to non-obvious Sociology. Tradução de Tania Quintaneiro. New York: Oxford University Press, 1982.

CHARTIER, R. Pierre Bourdieu e a História: debate com José Sérgio Leite Lopes. Topoi, Rio de Janeiro, p. 139-182, mar. 2002.

DI PIETRO, M. S. Z. Direito Administrativo, 20a ed. São Paulo: Atlas, 2007.

DALLARI, D. de A. Degradação do Judiciário. Folha de São Paulo, 08 maio 2002.

DURKHEIM, E. As formas elementares da vida religiosa: o sistema totêmico na Austrália. São Paulo: Martins Fontes, 1996.

FAORO, R. Os donos do poder: formação do patronato político brasileiro, $2^{\text {a }}$ ed. rev. e aum. Porto Alegre: Globo; São Paulo: Edusp, 1975.

FERRAZ, Tércio Sampaio. Prefácio. In: Eichmann em Jerusalem: um relato sobre a banalidade do mal. São Paulo: Diagrama \& Texto, 1983.

FOUCAULT, M. A ordem do discurso. São Paulo: Loyola, 1970.

GUIMARÃES, M. O Juiz e a Função Jurisdicional. Rio de Janeiro: Forense, 1958.

GROSSI, P. Mitologia Jurídica de La Modernidad. Madrid: Editorial Trotta, 2003.

HOBSBAWM, E. J.; RANGER, T. 0. A invenção das tradições, 3ª ed. Rio de Janeiro: Paz e Terra, 2002.

SADEK, M. T.; BENETI, Sidnei Agostinho; FALCÃO, Joaquim de Arruda. Magistrados: uma imagem em movimento. Rio de Janeiro: FGV, 2006.

SANT'ANA JÚNIOR, H. A.; SILVA, S. C. da. Taim: conflitos socioambientais e estratégias de defesa do território. Revista Pós-Ciências Sociais, v. 7, n. 13, 2010. Disponivel em: http://www.periodicoseletronicos.ufma.br/index.php/rpcsoc/article/ view/177/125. Acesso em: 22 de fev. 2012.

SANT'ANA JÚNIOR, H. A.; TEISSERENC, M. J. da S. A. Apresentação - Novos arranjos Territoriais e a Ação Pública em Territórios franceses e na Amazônia brasileira. Revista Pós-Ciências Sociais, v.
9, n. 18, 2012. Disponível em: http://www.periodicoseletronicos. ufma.br/ index.php/rpcsoc/article/ view/1356. Acesso em: 23 de fev. 2012.

LAHIRE, B.; CLASEN, J. A. Homem Plural: os determinantes da ação. Petrópolis (RJ): Vozes, 2002.

MELLO, M. A. Palavras dos Ministros: entrevistas. 2001. Disponível em: http://www.stf.jus.br/ arquivo/biblioteca/PastasMinistros/MarcoAurelio/ Entrevistas/2001_jun_01.pdf. Acesso em 24 de nov. 2012.

O’ DWYER, E. C. Nation Building e relações com o Estado: o campo de uma antropologia em ação. In: ZHOURI, A. (Org.). Desenvolvimento, Reconhecimento de Direitos e Conflitos Territoriais. Brasília: ABA Publicações, 2012.

OLIVEIRA FILHO, J. P. Os Instrumentos de Bordo: expectativas e possibilidades de trabalho do antropólogo em laudos periciais. Revista Nanduty, Dourados (MS), v. 1, n. 1, 2012. Disponível em: http://www.periodicos.ufgd.edu.br/index.php/ nanduty/article/view/2297/1359. Acesso em: 23 nov. 2013.

.ALMEIDA, A. W. B. de. Indigenismo e territorialização: poderes, rotinas e saberes coloniais no Brasil contemporâneo. Rio de Janeiro: Contra Capa, 1998.

PACHUCANIS, E. B. Teoria geral do direito e marxismo. Tradução de Sílvio de Donizete Chagas. São Paulo: Acadêmica, 1988.

RANCIÈRE, J. O Desentendimento: política e filosofia. São Paulo: Ed. 34, 1996.

RANCIĖRE, J. Sur “le Maître Ignorant”. Multitudes, 01 nov. 2004. Disponivel em: http:// multitudes.samizdat.net/Sur-Le-maitre-ignorant. Acesso em: 14 nov. 2013.

RANCIĖRE, J. Atualidade de 0 Mestre Ignorante. Entrevista realizada por Patrice Vermeren, Laurence Cornu e Andrea Benvenuto. Disponível em: http://www.cedes.unicamp.br, 2003. Acesso em: 22 out. 2013.

The Hatred of Democracy. Translation by Steve Corcoran. Verso, 2006. 
RIBAS, C. M. Justiça em tempos sombrios: a justiça no pensamento de Hanna Arendt. Ponta Grossa (PR): UEPG, 2005.

SANTILLI, P. Pemongon Patá: território Macuxi, rotas de conflito. São Paulo: Unesp, 2001.

Entrevista concedida à TV Navegar sobre Koch Grumberg, o pai de Macunaíma. 26 jun. 2010. Disponivel em: http://tvnavegar.com.br/video/?idv=104. Acesso em: 22 jul. 2012.

VIEIRA, 0. V. Supremocracia. Revista de Direito GV, São Paulo, v. 4, n. 2, dez. 2008. Disponível em: http://www.scielo.br/scielo.php?script=sci_arttextEtpid=S1808-24322008000200 005\&tn$\mathrm{g}=$ enftnrm=iso $>$. Acesso em: 10 abr. 2013.

YAMADA, É. M.; VILLARES, L. F. 2010 a. Julgamento da Terra Indígena Raposa Serra Do Sol: todo dia era dia de índio. Revista de Direito GV, São Paulo, n. 6, p. 143-158, jan./jun.

YAMADA, É. M. 2010. 0 legado do presidente do STF Gilmar Mendes aos povos indigenas. Instituto Socioambiental. Disponivel em http://www. socioambiental.org/pt-br/blog /blog-do-isa/o-legado-do-presidente-do-stf-gilmar-mendes-aos -povos-indigenas. Acesso em: 22 jul. 2012.

ZHOURI, A. "Adverse Forces" in the Brazilian Amazon: developmentalism versus environmentalism and Indigenous rights. The Journal of Environment \&t Development, v. 19, p. 252-273, 2010. 
RESUMO

Este artigo tem como foco de análise a decisão proferida pelo Supremo Tribunal Federal envolvendo a demarcação da Terra Indígena Raposa Serra do Sol. 0 acoplamento de condicionantes à decisão principal significou uma inovação do STF, pois elas não existem no ordenamento jurídico nem mesmo como salvaguardas institucionais, como se pretendeu estabelecer. Assim, embora o resultado final tenha sido favorável à TIRSS, o acolhimento das condicionantes pela maioria dos ministros mostrou a parcialidade da universalidade dos direitos, alocando os direitos indígenas em uma posição de segunda categoria. Nesse sentido, juntamente com a Súmula 650 e com o Decreto 1775/96, as condicionantes integram o que chamamos de racionalidade $d a$ injustiça. Compondo esse cenário, a força emanada pelos símbolos do universo jurídico contribui para a expressão de um direito mitificado, no qual essa mesma racionalidade, coberta pela toga e enobrecida por ritos e anéis, transformou-se no principal braço de um direito injusto.

\section{PALAVRAS-CHAVE}

Justiça. Racionalidade. Supremo Tribunal

Federal. Terra Indígena Raposa Serra do Sol

\section{ABSTRACT}

This paper objectives on analysis of the decision pronounced by the Supreme Court involving the demarcation of the Terra Indigena Raposa Serra do Sol. The coupling conditions to the principal decision meant a STF innovation because they do not exist in the legal system even as institutional safeguards, as if intended to establish. So while the end result has been favorable to TIRSS, the host of the conditions for the majority of the ministers showed partiality of the universality of rights, allocating indigenous rights in a position of second category. In this sense, along with the Precedent 650 and Decree 1775/96, the conditions are part of what we call rationality of injustice. Compounding this scenario, the force emanating from the symbols of the legal universe contributes to the expression of a mythologized law, in which the same rationality, covered by the toga and ennobled by rites and rings, has become the main arm of an unjust law.

\section{KEYWORDS}

Justice. Rationality. Supreme Court. Indigenous Land Raposa Serra do Sol. 